УАК 616.314-085.462

(сМ. Я. Нідзельський, К. Г. Зінкевич

ВАНЗ України «Українська медична стоматологічна академія», м. Полтава

\title{
Конструктивні особливості зубоясенних запобіжників та їх вплив на окремі показники організму в тренувальному процесі боксерів
}

Резюме.Використання зубоясенних запобіжників спортсменами, які займаються боксом, має ряднедоліків, що призводить до порушення функції дихання під час фізичного навантаження, до гіпоксії крові через недостатню фіксацію запобіжника, зменшують концентраціюуваги спортсмена та викликаютьдискомфорт у порожнині рота. В статті показано порівняння вивчених показників. Встановлено, що застосування зубоясенних запобіжників, виготовлених за запропонованою конструктивною методикою, покращує параметри, які вивчаються, і поліпшує підготовку боксерів до змагань.

Ключові слова: зубоясенні запобіжники, функціональні навантаження, фріксація.

\author{
М. Я. Нидзельский, К. Г. Зинкевич \\ ВГУЗ Украины «Украинская медицинская стоматологическая академия», \\ г. Полтава
}

\section{Конструктивные особенности зубодесневых предохранителей и их влияние на отдельные показатели организма в тренировочном процессе боксеров}

Резюме. Использования зубодесневых предохранителей спортсменами, которые занимаются боксом, имеет ряд недостатков, которые приводят к нарушению функции дыхания во время фризической нагрузки, к гипоксии крови через недостаточную фиксацию предохранителя, уменьшают концентрацию внимания спортсмена и вызывают дискомфорт в полости рта. В статье приведено сравнение изученных показателей. Установлено, что применение зубодесневых предохранителей, изготовленных по предложенной конструктивной методике, улучшает параметры, которые изучаются, и улучшает подготовку боксеров к соревнованиям.

Ключевые слова: зубодесневые предохранители, функциональные нагрузки, фиксация.

M. Ya. Nidzelskyy, K. H. Zinkevych

HSEI of Ukraine «Ukrainian Medical Stomatological Academy», Poltava

\section{Design features of periodontal fuse and their impact on selected indicators body in the training process of boxers}

Summary. Years of experience using periodontal fuse athletes involved in boxing have several drawbacks that lead to dysfunction of breath during exercise, hypoxia due to inadequate fixation of blood safety, reduce concentration and cause the athlete discomfort in the mouth.In the article the comparison of the 
studied parameters was given. It was established that the use of periodontal fuse the proposed constructive method of improving production parameters studied, improving training boxers for competition.

Key words: periodontal fuses, functional load, lock.

Вступ. Спортивні травми зубощелепної системи не тільки болісні, але і вимагають довгого та складного лікування. Тому питання профілактики зубощелепних травм стає все білыш актуальним і займає дуже важливе місце у справі збереження здоров'я боксерів [1,2]. Одним із обов' язкових засобів профрілактики щелепно-лицевого травматизму є зубоясенний запобіжник, що пом'якшує удари, сила яких може призвести до травмування ясен, губ, альвеолярного відростка щелепи, зубів та скронево-щелепного суглоба [3-5].

У даний час досить широко застосовують спортивні зубоясенні запобіжники, які здійснюють захист присінка порожнини рота, зубних рядів, що підтримують фріксоване положення нижньої щелепи в період тренувань і змагань. Однак в умовах дороговартості, недостатньої проінформованості молоді спортсмени використовують дешеві конструктивні матеріали, які дозволяють виготовити зубоясенні зупобіжники в домашніх умовах без врахування індивідуальних особливостей конструкції. Такі зубоясенні запобіжники покривають зубний ряд верхньої щелепи частково і не мають вестибулярного валика. Ці запобіжники із спортивно-лікувальної точки зору не забезпечують необхідного захисту. Вони мають невиправдану товщину, викликають дискомфорт у спортсменів $[6,7]$. Фіксація таких зубоясенних запобіжників значно гірша, ніж у індивідуальних, вони швидко розтягуються і мають короткий термін експлуатації [6, 8].

Одна з основних вимог до спортивних зубоясенних запобіжників - це їх індивідуальність, функціональність, комфортність, міцність, біосумісність та відсутність негативного впливу на мікробіоценоз порожнини рота $[5,8]$. Правильно виготовлений зубоясенний запобіжник знижує ризик пошкодження шиї, струс головного мозку, внутрішній крововилив і смертельно небезпечні травми.

Однак і ці зубоясенні запобіжники недосконалі, оскільки конструкції їх ускладнюють функцію дихання спортсменів; недостатня фіксація їх призводить до випадання із порожнини рота та значного травматизму, а відчуття дискомфорту зменшує концентрацію і увагу боксера $[2,9]$.

Метою дослідження стало, порівнюючи це, отримати уявлення про зміни фрункцій зовнішнього дихання, зміни складу крові спортсмена, вивчення порушень дискомфорту та кріплення залежно від конструктивних особливостей зубоясенних запобіжників, виготовлених за загальноприйнятою та запропонованою нами технологією.

Матеріали і методи. В 36 боксерів у період тренування на «лапах», що давало змогу градуювати ступінь навантаження, вивчали роль різних конструкцій запобіжників і їх вплив на функцію зовнішнього дихання. За допомогою спеціальної маски на вусі боксера закріплювали датчик оксигенометра. Ао і після кожного раунду вимірювали артеріальний тиск і пульс спортсмена. Аослідження проводили в один час доби. Контролем слугували групи цих же боксерів, які не одягали запобіжники. В експерименті вивчали ступінь фріксації запобіжника на щелепах шляхом підвішування до нього важеля.

Запобіжники виготовляли з матеріалу «Боксил-екстра» за наступною схемою: отримували повні анатомічні відбитки еластичним відбитковим матеріалом з верхньої та нижньої щелеп, за отриманими відбитками відливали гіпсові моделі, на яких відмічали межі зубоясенних запобіжників. Потім їх складали у положення центральної оклюзії і гіпсували в оклюдаторі. Потім зубні ряди роз'єднували на $2-3$ мм і моделювали зубоясенний запобіжник із воску. З боку присінка порожнини рота зубоясенний запобіжник доходить до перехідної складки, огинаючи уздечки і тяжі слизової оболонки, покриває верхньощелепні горбки. На піднебінні межа зубоясенних запобіжників охоплює зону поперечних складок, залишаючи вільним піднебінний шов. При цьому необхідно, щоб зубоясенний запобіжник покривав зубні ряди, тверде піднебіння і вестибулярний скат альвеолярного 
відростка [4] (методика виготовлення зубоясенного запобіжника, яку ми запропонували нами, подана заявка на винахіА).

Результати досліджень та їх обговорення. За отриманими результатами вивчення фріксації зубоясенних запобіжників, виготовлених за технологіями, встановлено: максимальний тяж, що скидає зі щелепи боксерів зубоясенний запобіжник, виготовлений за загальноприйнятою технологією, знаходиться в межах $(122,7 \pm 7,2)$ г. Тоді як зубоясенні запобіжники, виготовлені за запропонованою нами технологією, максимальний тяж, що складає запобіжник, збільшується до $(231,9 \pm 8,56)$ г (рис. 1$)$

Статистична обробка отриманих результатів показала достовірну різницю у величинах, що характеризують ефективність утримання зубоясенного запобіжника в групах порівняння.

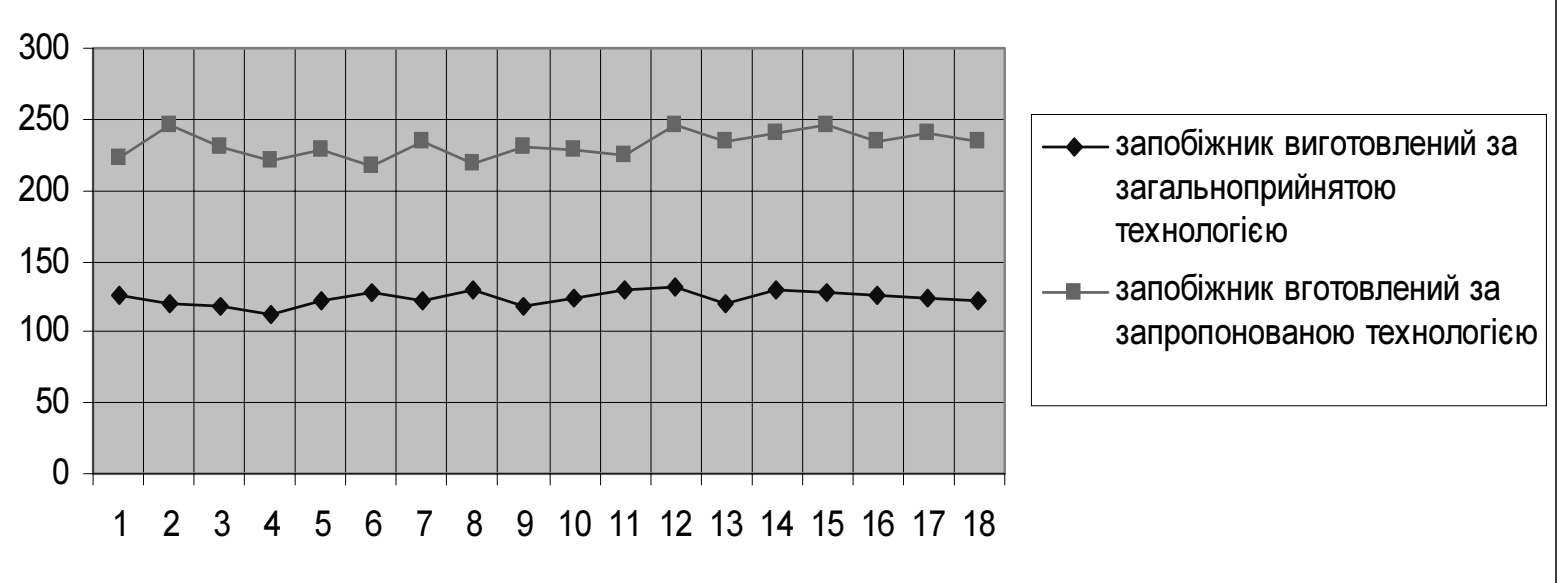

Рис. 1. Показники виміру ступеня фріксації зубощелепного запобіжника на щелепах шляхом підвішування важеля.

Порівнюючи показники функції дихання у боксерів при фрізичному навантаженні виявлено, що зубоясенний запобіжник, виготовлений за запропонованою нами технологією, значно зменшує показники функціонального дихання, порівняно з групою боксерів, які користувалися запобіжниками, виготовленими за загальноприйнятою технологією.
Отримані результати дослідження свідчать про значний відсоток зменшення дискомфорту в боксерів, які користувалися зубоясенними запобіжниками, порівняно з користувачами зубоясенних запобіжників, які були виготовлені за запропонованою нами технологією (рис. 2).

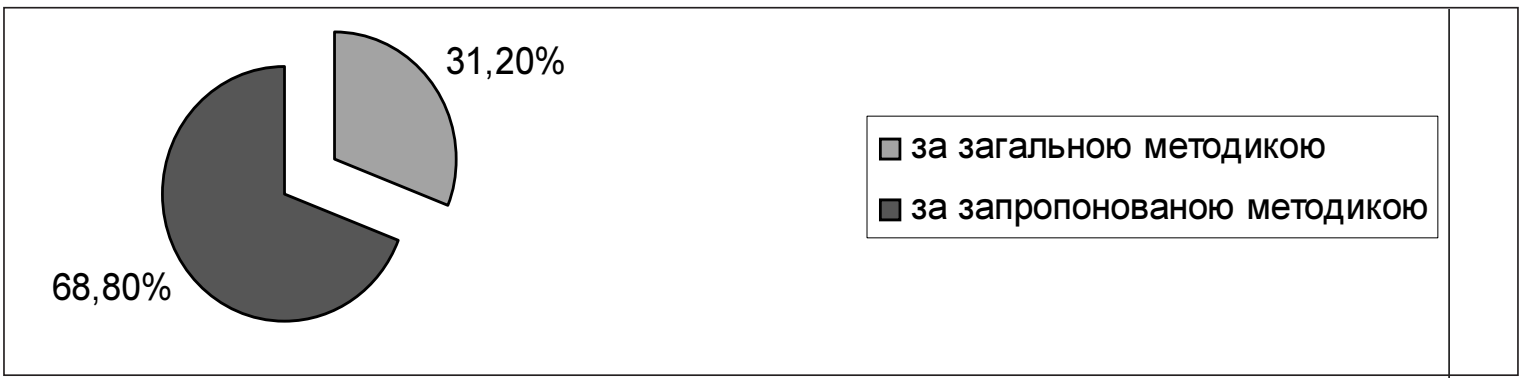

Рис. 2. Відсоткове співвідношення показників відчуття дискомфорту боксерів, які користувались запобіжником, виготовленим за різними технологіями.

Показники оксигинації крові при фрізичних навантаженнях у боксерів також різнились і залежали від конструктивних особливостей зубоясенних запобіжників. 
Висновки. Отримані результати свідчать про покращення вивчених показників у боксерів, які користувались зубоясенними запобіжниками, виготовленими за запропонованою нами технологією.

При дослідженні спортсменів під час фізичних навантажень на тренуванні на "лапах» виявлено, що запропонована конструкція зубоясенних запобіжників показує кращі результати з боку функції дихання, фіксації, гіпоксії

\section{Список літератури}

1. Ray P. Padilla Лечение и профилактика переломов альвеол и сопутствующих повреждений / Padilla P. Ray, L. Alan Feisenfeld // Стоматолог. - 1999. - № 5. - C. $16-18$.

2. Labella C. R. Effect of mouthguards on dental injuries and concussions in college basketball / C. R. Labella, B. W. Smith, A. Sigurdsson // Med. Sci. Sports Exers. 2002, Jan. - Vol. 34, № 1. - P. $41-44$.

3. Миронова 3. С. Спортивная травматология / Миронова З. С., Морозова Е. М. - М. : Физкультура и спорт, 1976. - С. $11-15,31,32,64-69,75-77,89-92$. 4. Тониян Т. А. Закрытие черепно-мозговые травмы и их последствия у спортсменов : автореф. дисс. на соискание научн. степени канд. мед. наук : 06.02.09. 1969. - C. $3-19$.

5. Raschka C. 15 jahrige Versichherungsstatistic zu Inzidenzen und Unfallhergangstypen von Kampfsportverletzungen im Landessportbund Rheinland - Pfalz (15 years insurance statistics of incidents and accident types of combat sports injuries of the RhinelandPfalz Federal Sports Club) / C. Raschka, M. Parzeller, крові, ніж зубоясенні запобіжники, виготовлені за загальноприйнятою технологією.

Перспективи подальших Аосліджень. Отримані результати будуть використані в подальших наукових дослідженнях щодо впливу конструктивних особливостей зубоясенних запобіжників на функціональні показники організму в спортсменів, які займаються боксом.

W. Banzer . - Sportverletz - Sportschaden, 1999, Mar. - B.13, № 1. - S. 17-21.

6. Increasing mouthguards usage among junior rugby and basketball players / G. Jallen, R. J. Donovan, J. Clarkson [et al.] // Aust. N. Z. J. Public Health. 2001, Jun. - Vol. 25, № 3. - P. 250 - 252.

7. Jolly K. A. Promotion of mouthguards among amateur football players in Victoria / K. A. Jolly, L. B. Messer, D. Manton // Aust. N. Z. J. Public Health. - 1996, Dec. - Vol. 20, № 6. - P. 630 - 639.

8. Томилин В. Г. Разработка и клиническое обоснование применения индивидуальных зубодесневых предохранителей из материала (Боксил-экстра): авторефр. Аисс. на соискание научн. степени канд. мед. наук. Харьков, 2005. - 154 с.

9. Ибрагимов Т. И. Применение современных защитных спортивных капп для профилактики челюстнолицевой области / Т. И. Ибрагимов, А. В. Хан : Сборник научных трудов по материалам научно-практической конференции «Гармонизация лечебного и учетного процесса в ортопедической стоматологии». - M., 2009. - C. 257-261.

Отримано 04.04.14 